\title{
Modernizacja zabytkowego zespołu dworsko-pałacowego w Cianowicach
}

\author{
Joanna Gil-Mastalerczyk \\ e-mail:jmastalerczyk@tu.kielce.pl \\ Zakład Architektury Użyteczności Publicznej i Urbanistyki, Katedra Architektury \\ i Urbanistyki, Wydziat Architektury i Budownictwa, Politechnika Świętokrzyska \\ Department of Architecture and Town Planning, Faculty of Civil Engineering \\ and Architecture, Kielce University of Technology
}

\section{Regina Gil \\ e-mail: regina.gil@op.pl}

Krakowska Akademia im. A. Frycza-Modrzewskiego w Krakowie

Andrzej Frycz Modrzewski Krakow University in Cracow

\begin{abstract}
Streszczenie: Zabytkowe założenie architektoniczno-ogrodowe w Cianowicach pod Krakowem, jako wielkie dobro przekazane przez poprzednie pokolenia, stało się potwierdzeniem, że niezależnie od stopnia zachowania zabytku, poprzez właściwą ingerencję z użyciem środków współczesnych i wprowadzeniem nowej substancji, możliwe jest przywrócenie ważnego znaczenia obiektowi i miejscu. Pozwoliło to na nowo odkryć cenne dziedzictwo historyczne. Przywrócona na nowo funkcja, stała się narzędziem do tego, by zabytek mógł funkcjonować i efektywnie oddziaływać na otoczenie, społeczność - w dobie postępującego na świecie szybkiego rozwoju cywilizacyjnego, niosącego za sobą zagrożenia prowadzące do degradacji krajobrazu kulturowego, w tym zabytkowych założeń dworsko-parkowych.
\end{abstract}

Słowa kluczowe: modernizacja zabytku, pałac, dwór, Cianowice

\section{Wstęp. Położenie, uwarunkowania formalno-prawne}

W niewielkiej miejscowości Cianowice koło Skały, w województwie małopolskim, położony jest zespół dworski oraz otaczający go park z pięknym drzewostanem ${ }^{1}$. Cały zespół zlokalizowany jest w zachodniej części wzniesienia, na zachód od drogi krajowej Kraków-Skała, na południowy zachód od centrum wsi. Od strony północnej teren sąsiaduje z zabudowaną działką - budynkami szkolnymi, a z pozostałych stron działkami zabudowanymi częściowo - budownictwem jednorodzinnym. Teren zespołu pałacowego w całości jest ogrodzony oraz posiada istniejący dostęp komunikacyjny, przez wjazd na działkę z drogi gminnej. Teren jest całkowicie uzbrojony.

W ramach modernizacji i adaptacji zabytkowego obiektu, przeprowadzonej w latach 2012-2015, wykonane zostały roboty budowlane polegające na przebudowie, rozbudowie, nadbudowie oraz zmianie sposobu użytkowania budynku dworskiego na budynek mieszkalny jednorodzinny dwupokoleniowy - zgodnie z decyzją o pozwolenie na budowę wydaną przez Starostę Krakowskiego oraz decyzją Małopolskiego Konserwatora Zabytków w Krakowie, z 2012 r. 
W ramach całego przedsięwzięcia inwestycyjnego wykonane zostały także: budowa towarzyszącej infrastruktury technicznej (dojść, dojazdów, miejsc postojowych) z budową wewnętrznych instalacji (wodno-kanalizacyjnej, gazowej, c.o., wentylacji mechanicznej, instalacji chłodzenia, instalacji energii elektrycznej - niskoprądowej i odgromowej) i kotłownią gazową.

W związku ze zmianą właściciela nieruchomości, zakładana uprzednio usługowa funkcja obiektu (budynek imprez okolicznościowych wraz z pomieszczeniami biurowymi, gościnnymi i socjalnymi), zmieniła się na budynek mieszkalny - kilkupokoleniowy, i jest powrotem do pierwotnej historycznej funkcji tego budynku².

\section{Stan istniejący}

W skład zespołu dworsko-parkowego w Cianowicach, wchodzi wolnostojący budynek dworu, otaczający go park z drzewostanem oraz budynek gospodarczy - usytuowany od strony północnej pałacu (niewpisany do rejestru zabytków, objęty ochroną konserwatorską).

Budynek dworu powstał około 1890 r. $^{3}$ Zaprojektowany został przez Teodora Talowskiego, na zlecenie ówczesnych właścicieli Cianowic - Dobieckich, budowniczych obiektu.

Dzieje budowli do 1945 r. nie są bliżej znane. W roku 1945 rozpoczął się nowy okres w historii cianowickiego dworu, który przestał pełnić funkcję pierwotną - rezydencjonalną, związaną z miejscowym majątkiem ziemskim. Dwór wykorzystywany był przez różne instytucje do różnych potrzeb, ulegał stopniowej dewastacji, a jego wystrój niszczeniu. O ile stan techniczny budynku podlegał bieżącym remontom, to wystrój architektoniczny i plastyczny budowli, z biegiem lat był uszczuplany i likwidowany, zanikał.

Od 2006 r. obiekt pozostawał niezabezpieczony i pozbawiony opieki, co w znaczący sposób wpłynęło na zdegradowanie zinwentaryzowanych elementów wystroju i wyposażenia wnętrz ${ }^{4}$. Większość elementów uległo dewastacji (stolarka zdemontowaniu, a ocalałe ruchome elementy zabytkowe bądź ich zachowane partie, pozostały w bardzo złym stanie technicznym). Podobnie, znacznej degradacji uległ tynkowy wystrój elewacji - ubytki profilowań i tynków do wątku ceglanego, zasolenia i zawilgocenia lokalne tynków, nawarstwienia tynków typu biologicznego.

Niezabezpieczony oraz pozbawiony opieki zabytkowy obiekt, zarówno w wyniku oddziaływania warunków atmosferycznych, jak i nieogrzewanych i pozbawionych w większości szklenia pomieszczeń, ulegał znaczącej dewastacji i sukcesywnemu rozkradaniu elementów.

W równie złym stanie pozostaje zabytkowy park towarzyszący całemu założeniu. Nieużytkowanie go przez wiele lat doprowadziło do jego ogólnej dewastacji oraz do zatracenia części ozdobnej wokół obiektu. Penetracja parku pozwala zorientować się, że kiedyś istniał tu pięknie urządzony teren, co potwierdzają archiwalne zdjęcia z okresu międzywojennego. Aktualnie najcenniejszy w parku jest drzewostan. Nie zachowały się krzewy i kompozycje kwiatowe.

2 Opublikowanie dokumentów i przeprowadzonych prac renowacyjnych pałacu w Cianowicach stało się możliwe dzięki ogromnej życzliwości i uprzejmości Inwestora Pana M. Adamowicza i śp. K. Adamowicz.

3 Kamienne wątki ścian i sklepień komór piwnicznych północnej partii budynku pochodzą z okresu budowy - IV w. XIX w., natomiast z połowy XX w. pochodzi część piwnic dobudowana z cegły maszynowej

4 W 2006 r. przeprowadzona została inwentaryzacja elementów zabytkowego wystroju i wyposażenia wnętrz, za: Dwór w Cianowicach. Gmina Skała. Zestawienie elementów zabytkowych. Aktualizacja. Projektant Marek. M. Łukacz, Marek J. Łukacz, Kraków 2010. 

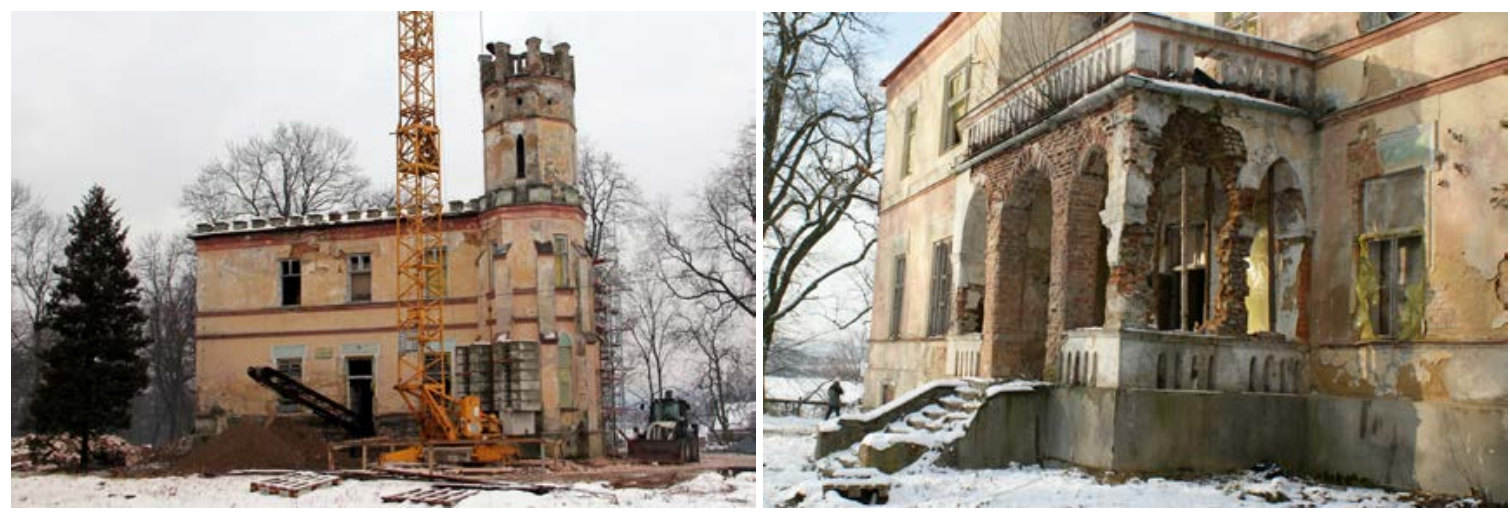

Ryc. 1. Pałac w Cianowicach, widok bryły pałacu, stan przed modernizacją, 2011 (źródło: dokumentacja Właściciela obiektu, dostęp 2015)

Palace Cianowice view blocks of the palace, the state before the modernization, in 2011 (documentation of the owner of the object, Access 2015)

\section{Projektowane zagospodarowanie terenu}

W chwili obecnej wokół pałacu zaprojektowano i odbudowano kompozycje zieleni oraz zapewniono właściwą pielęgnację istniejącego drzewostanu. W otoczeniu obiektu odbudowany został układ ciągów pieszo-jezdnych ${ }^{5}$. Zrekonstruowano ścieżki spacerowe w części północno-wschodniej parku. Nawierzchnię wszystkich ścieżek i ciągów pieszo-jezdnych przewidziano z kostki granitowej - w odcieniach szarości, płomieniowanej, ułożonej na podsypce cementowo-piaskowej.

W ramach zagospodarowania terenu, w związku z obowiązującymi przepisami budowlanymi, zaprojektowane zostały również miejsca postojowe dla samochodów, zbiornik na wody opadowe oraz niezbędna infrastruktura techniczna.

Ogólnie należy stwierdzić, że w projektowaniu całego założenia ważną rolę odegrało dążenie do zachowania zabytkowego charakteru otoczenia.
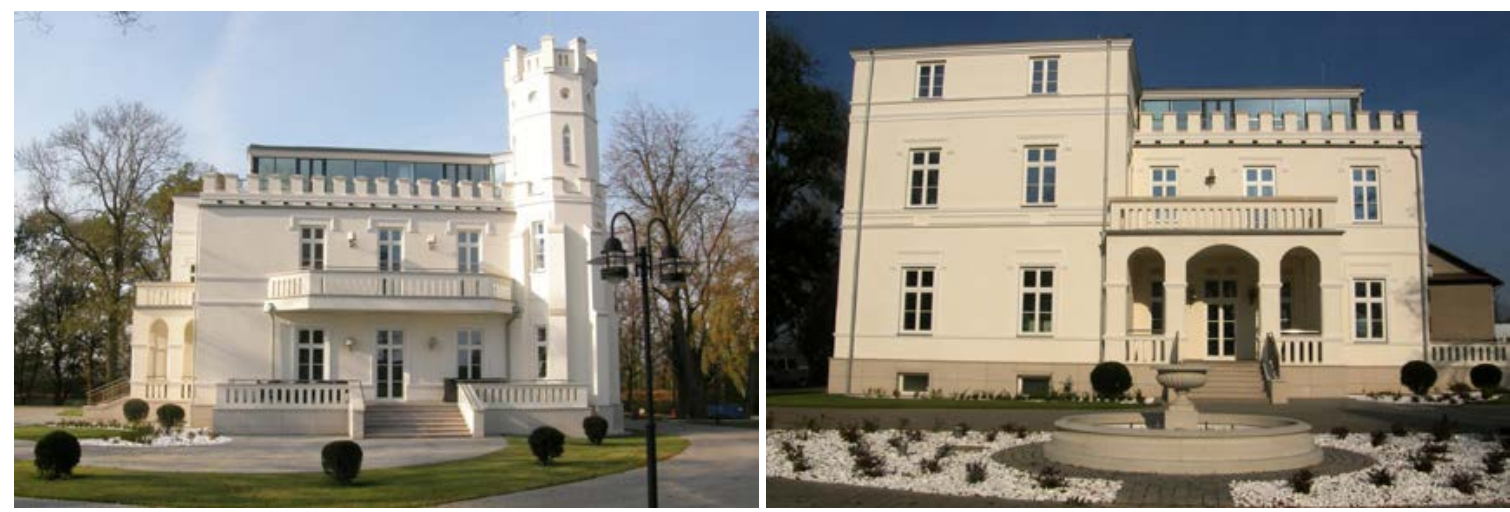

Ryc. 2. Pałac w Cianowicach, widok pałacu z otoczeniem, stan po modernizacji, 2014 r. (źródło: dokumentacja Właściciela obiektu, dostęp 2015).

Palace Cianowice, view of the palace with the environment, the state of the modernization, 2014. (documentation owner of the object, Access 2015). 


\section{Modernizacja i adaptacja pałacu. Analiza stopnia zachowania układu zabytkowego. Układ funkcjonalno-przestrzenny}

W wyniku generalnego remontu konserwatorskiego, zarówno technicznego, ze względu na występujące niekorzystne warunki gruntowe, przewidziano podbicie wszystkich istniejących fundamentów - do poziomu warstwy skalnej. Istniejące ściany piwnic oraz fundamenty części niepodpiwniczonej obiektu, zostały również podbite i zyskały izolację przeciwwodną.

Nad piwnicą zachowano kolebki ceglane oraz strop Kleina - z nowymi warstwami podłogowymi. Nad częścią piwnic (tj. tam gdzie budynek nie był podpiwniczony i posiadał jedynie podłogę na gruncie), parterem i pierwszym piętrem zaprojektowano prefabrykowane płyty żelbetowe, oparte na dolnych stopkach belek stalowych, zasypane keramzytem.

W całości zaprojektowana została nowa konstrukcja dachu i wykonana ze współczesnych materiałów, z pokryciem z blachy tytanowo-cynkowej. Wszystkie obróbki blacharskie, jak ofasowania, rynny i rury spustowe wymienione zostały na nowe - z blach niekorodujących, wraz z precyzyjnym określeniem i nadaniem odpowiednich kątów spadków.

Całościowo odtworzone zostały zewnętrzne schody wejściowe - prowadzące do budynku.

W wyniku generalnego remontu wszystkie zewnętrzne ściany i elewacje budynku zostały wzmocnione oraz zabezpieczone. Przywrócono im utracone parametry wytrzymałościowe. Wykonano prace o charakterze estetycznym, z przywróceniem pierwotnej kolorystyki elewacji, detalu architektonicznego oraz stolarki okiennej. Ze względu na zły stan zachowania stolarki zewnętrznej przewidziano jej wymianę z powtórzeniem formy podziałów i profili.

W ramach przeprowadzonych badań chemicznych określone zostały stopnie zasolenia warstw tynku, celem wytypowania elementów do wymiany i ustalenia tynków renowacyjnych, a także wykonane badania stratygraficzne na obecność pierwotnej kolorystyki elementów wystroju elewacji - warstw tynku i wystroju architektoniczno-rzeźbiarskiego.

Z uwagi na bardzo zły stan tynków, zmurszałych i zasolonych oraz zaawansowanie procesów niszczących, wszystkie tynki na ścianach zewnętrznych (od zewnątrz i od strony wewnętrznej) zostały skute. Ściany oczyszczono, szczeliny i pęknięcia zabezpieczono tynkiem renowacyjnym ze środkami osłonowymi ${ }^{6}$.

W efekcie etapów odnowy elewacji budynku pomalowano warstwy tynków i dokonano scalenia kolorystycznego wystroju architektoniczno-rzeźbiarskiego, zgodnie z pierwotną kolorystyką.

Wszelkie prace naprawczo-konserwatorskie wykonano z zastosowaniem gotowych materiałów firmowych oraz w oparciu o szczegółowe technologie, z doborem odpowiedniego materiału. Wszystkie tynki zewnętrzne na elewacjach budynku oraz wieży wykonane zostały zgodnie z programem konserwatorskim. W pracach naprawczo-konserwatorskich przy tynkach zastosowano technologię gotowych materiałów firmowych posiadających atest WTA.

W wyniku projektowanych robót całkowitej zmianie uległ wewnętrzny układ funkcjonalno-przestrzenny budynku?

6 Wieża (stary wạtek - wewnątrz i zewnątrz) - w miejscach zawilgoconych, zagrzybionych i zasolonych wykonano warstwy tynku renowacyjnego KEIM Porosan, posiadających certyfikat WTA. W przyziemnej części budynku oraz ok. $30 \mathrm{~cm}$ ponad poziom gruntu - założono warstwę uszczelniającą - KEIM Porosan Dichtungsschlamme (mineralny materiał powłokowy na bazie cementu, drobnych piasków i dodatków uszczelniających).

Krzyżowa obrzutka przekrywająca $50 \%$ podłoża grubości do $5 \mathrm{~mm}$ - przy użyciu materiału KEIM Porosan Trass Zementputz - tynk trasowo-cementowy, natryskowy poprawiający przyczepność w przyziemnej części budynku. Zagłębienia, dziury oraz silne nierówności wypełniono i wyrównano materiałem KEIM-Porosan Ausgleichsputz - przeznaczonego do wilgotnych, zasolonych murów.

Następnie dwie warstwy tynku renowacyjnego - KEIM Porosan Trass Sanierputz - tynk hydrauliczny szerokoporowy na bazie wapna trasowego, białego cementu, piasku i dodatków o dużej wytrzymałości, przeznaczonego do wilgotnych zasolonych murów, stosowany wewnątrz i na zewnątrz budynku. W celu uzyskania jednakowej faktury powierzchni elewacji zastosowano tynk cienkowarstwowy wapiennocementowy z dodatkiem włókien zbrojących KEIM Universalputz (uziarnienie 0,6 mm) na wieży i system docieplenia (na siatkę z klejem).

Wykończenia malarskie. Gruntowanie wszystkich powierzchni materiałem Keim Soldalit Fixativ - specjalistycznym środkiem gruntującym na bazie spoiwa zolowo-krzemianowego, o wysokiej paroprzepuszczalności i stabilności w każdych warunkach atmosferycznych.

Wykonanie warstwy wierzchniej - malowanie najwyższej jakości farbą zolowo-krzemianową KEIM Soldalit w ustalonej kolorystyce (pierwsza warstwa z dodatkiem ok. 10\% Keim Soldalit Fixativ). Mineralna farba elewacyjna o bardzo wysokiej paroprzepuszczalności, zabezpieczająca podłoża mineralne przed czynnikami atmosferycznymi.

7 Powierzchnia zabudowy obiektu: $388,95 \mathrm{~m}^{2}$, powierzchnia użytkowa: $1064,46 \mathrm{~m}^{2}$, powierzchnia całkowita: $1358,9 \mathrm{~m}^{2}, \mathrm{kubatura:}^{5268,71} \mathrm{~m}^{3}$, ilość kondygnacji nadziemnych: 3, ilość kondygnacji podziemnych: 1, za: Projekt budowlany z 2012 r. (źródło: dokumentacja projektowa Właściciela obiektu). 
Zaprojektowane zostały reprezentacyjne wachlarzowe schody wewnętrzne, jako żelbetowe, wykończone białym marmurem.

Na parterze, piętrze pierwszym oraz piętrze drugim zaplanowano funkcje mieszkalną, gabinety, i inne pomieszczenia towarzyszące (kuchnie, łazienki, toalety, garderoby i itp.). Na piętrze zaplanowano głównie sypialnie wraz z garderobami oraz oddzielnymi łazienkami.

W piwnicach zaprojektowane zostały pomieszczenia rekreacyjno-wypoczynkowe z basenem, jacuzzi oraz pomieszczenia o funkcji technicznej z kotłownią gazową.

Wszystkie pomieszczenia wyposażono w wentylację mechaniczną i klimatyzację. Instalacje wewnętrzne dostosowano do potrzeb nowej funkcji.

Tynki wewnętrzne wykonano, jako cementowo-wapienne, wykończone gładziami gipsowymi.

Kamienne wątki ścian i sklepień komór piwnicznych, zlokalizowanych w północnej partii budynku, pochodzące z okresu budowy - IV w. XIX w., oraz z połowy XX w. dobudowaną część z cegły maszynowej - poddano pracom konserwatorskim. Poprzez wzmocnienie techniczne materiałów usunięte i wstrzymane zostały procesy degradacyjne na sklepieniach i ścianach piwnic. Wprowadzono cyrkulację powietrza i ze względu na wysoki stopień zawilgocenia, w pierwszej fazie prac, osuszone zostały najstarsze wątki kamienne i ceglane. Następnie usunięto współczesne przemurowania partii wątków zaprawami cementowymi - powstałymi w wyniku doraźnych napraw. Zgodnie z założeniami programowymi, utrzymano i zachowano w maksymalnym stopniu najstarsze partie wykonane z wapienia łamanego. Przewidziane do ekspozycji wątki ścian i kolebkowych sklepień dwóch komór piwnicznych wykonanych z wapienia łamanego i cegły poddano konserwacji i wyeksponowano ich lica. Pozostałe wątki ścian i sklepień - innych piwnic, po przeprowadzeniu niezbędnych prac, pokryto tynkiem.

Wykończenie malarskie ścian wewnętrznych zabytkowej struktury, przeprowadzono po nałożeniu warstw tynku renowacyjnego i wcześniejszym zagruntowaniu wszystkich powierzchni specjalistycznym środkiem, na bazie spoiwa zolowo-krzemianowego, charakteryzującego się wysoką paro przepuszczalnością.

Wystrój wnętrz utrzymano w jasnej tonacji kolorystycznej. W sanitariatach i łazienkach, zarówno podłogi jak i ściany wyłożone zostały płytkami z naturalnych kamieni w jasnych odcieniach.
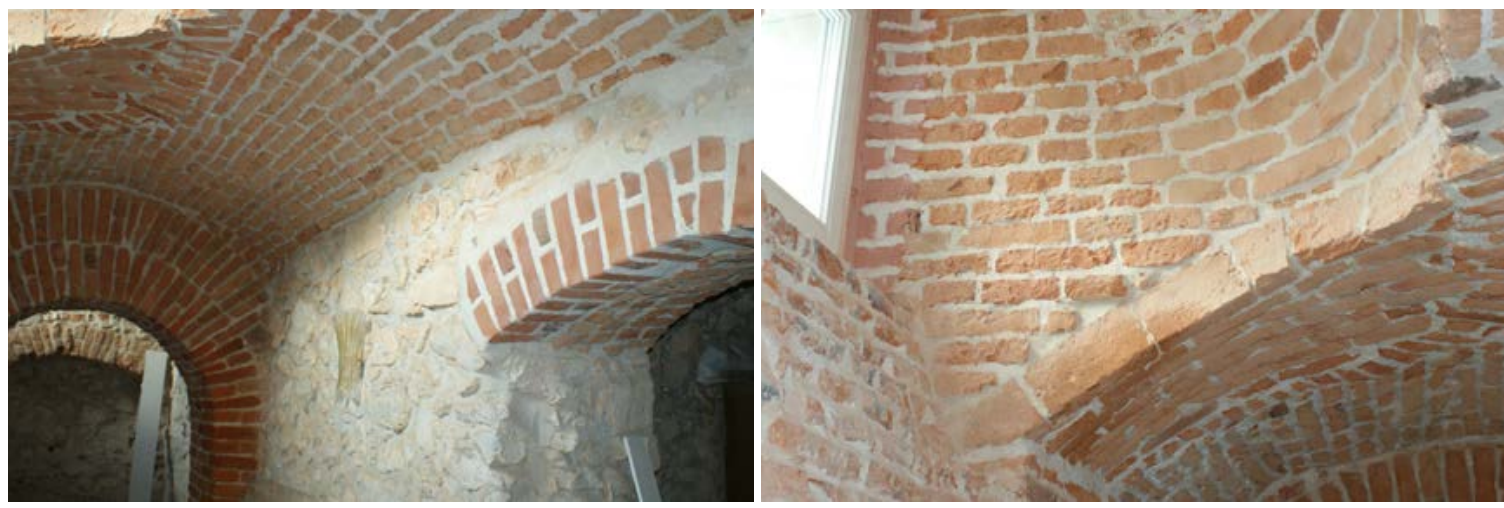

Ryc. 3. Pałac w Cianowicach, widok wnętrza piwnic, stan po modernizacji, 2014 (źródło: dokumentacja Właściciela obiektu, dostęp 2015).

Palace Cianowice, interior view basements, state after modernization 2014 (documentation of the owner of the object, Access 2015).

\section{Podsumowanie i wnioski}

Zabytki architektury dworskiej oraz zabytki ogrodowe są żyjącymi pomnikami, użytecznymi społecznie tak samo i dzisiaj [Majdecki, 1993]. Należy je więc pielęgnować i utrzymywać w dobrym stanie, gdyż są wielkim dobrem przekazanym przez poprzednie pokolenia.

Pałac w Cianowicach potwierdza, że niezależnie od stopnia zachowania zabytku, pozostaje on ważnym dziedzictwem kulturowym epoki, w której powstawał. Wraz z otaczającym założeniem parkowym, wnosi znaczący 
wkład w dorobek i rozwój kultury narodowej, prezentuje wartości historyczne, naukowe, artystyczne i przyrodnicze. Mówi o dokonujących się przemianach ustrojowo-gospodarczych, społecznych, terytorialnych, o panujących stosunkach międzyludzkich i funkcjonujących wśród nich obyczajów. Z tych powodów zabytki te powinny podlegać szczególnej ochronie, aby przetrwały dla przyszłych pokoleń, jako ważny element kształtowania się polskiej tradycji i kultury szlacheckiej.

Analiza przykładu w Cianowicach wskazuje, że niezbędne są pilne działania budowlane oraz skuteczna konserwacja obiektów dworskich, z maksymalnym zachowaniem oryginalnej substancji zabytkowej i ochroną wartości historycznych - w procesie adaptacji.

Andrzej Kadłuczka napisał: Jeśli zatem trwanie historycznego dzieła architektury lub urbanistyki (zabytku) jest zwiqzane z procesem zmian i przeksztatceń jego samego, jak i otaczajacej go przestrzeni, to ochrona oznaczać mu musi kontrolę i zarzadzanie tymi zmianami (...). Ochrona (...) opierać się musi na interwencji, do rozstrzygnięcia pozostaje natomiast jej skala i zasięg, a więc stopień interwencji [Kadłuczka, 2000].

Z uwagi na rosnący coraz bardziej zakres interwencji, wynikający z radykalnie zmieniających się współczesnych potrzeb, standardów czy funkcji, działania te, każdorazowo, muszą mieć indywidualny charakter. Dlatego ważne staje się sporządzenie pełnej dokumentacji, w szczególności rzetelnej inwentaryzacji, pod okiem konserwatora. Zgodnie z regulacjami prawnymi - przy wykonywaniu projektów konserwatorskich, nadzorze i realizacji prac przy obiektach zabytkowych - konieczne jest zapewnienie odpowiednio wykwalifikowanej i wykształconej kadry profesjonalnej, celem: zwrócenia szczególnej uwagi na właściwe rozwiqzzywanie problemów i dokonywanie wyborów na drodze do osiagnięcia wyznaczonego celu [Karta Krakowska 2000].

Często zdarza się, że celem zachowania konstrukcji zabytkowych budowli historycznych dla przysztych pokoleń inżynier bardzo często musi wybierać między niezgodnością z aktualnymi sztywnymi przepisami normowymi i aktami prawnymi a powrotem do czasów, kiedy powstawała oryginalna koncepcja i zamyst budowli, jej projekt i realizacja oraz utrzymanie [Malesza, Miedziałowski, Malesza, 2013], [lzquiredo-Encarnacion, 2012].

Wydaje się zatem, że warunkiem trwania zabytkowych założeń staje się ich upodmiotowienie. W założeniu pałacowym w Cianowicach, poprzez właściwą ingerencję z użyciem środków współczesnych i wprowadzenie nowej substancji - w sposób wykorzystujący i podkreślający wartości historyczne zabytku, możliwe stało się przywrócenie ważnego znaczenia temu obiektowi i miejscu. Pozwoliło to na nowo odkryć cenne dziedzictwo historyczne. Wydaje się również, że przywrócona na nowo funkcja, stanie się narzędziem do tego, by zabytek mógł funkcjonować i efektywnie oddziaływać na otoczenie, społeczność - w dobie postępującego na świecie szybkiego rozwoju cywilizacyjnego, niosącego za sobą zagrożenia prowadzące do degradacji krajobrazu kulturowego, w tym zabytkowych założeń dworsko-parkowych, zwłaszcza, że: Zostały one zdewastowane między innymi w wyniku wcześniejszych, (...) XX-wiecznych przemian ekonomiczno-gospodarczych i politycznych. Alarmująca sytuacja w tej dziedzinie zmusza światowe organizacje do podejmowania nowych działań w zakresie ochrony krajobrazu kulturowego. Działaniom tym sprzyja chęć powrotu do tradycji i potrzeba programu zrównoważonego rozwoju, jako "rozwoju zdolnego do zaspokajania potrzeb wspótczesnych w sposób nie naruszająy możliwości zaspokojenia potrzeb przyszłych pokoleń" [Grzesiak, 2004], [Baranowski 1998].

Konkludując, należy jeszcze raz podkreślić, że dziedzictwo architektoniczno-urbanistyczne oraz krajobrazowe jest wynikiem identyfikacji związanej z różnymi wydarzeniami historycznymi i kontekstem społeczno-kulturowym [Karta Krakowska 2000]. Celem przyszłych pokoleń jest ochrona tego dziedzictwa realizowana przez wiele rodzajów interwencji - prewencyjna konserwacja środowiska, doraźne utrzymywanie, naprawa, restauracja, renowacja czy rehabilitacja (rewaloryzacja) [Karta Krakowska 2000].

Modernizacja cianowickiego pałacu wraz z reaktywowaniem oryginalnej historycznej funkcji - o charakterze trwałym, przy wprowadzeniu nowych technologii, dostosowaniu do nowych standardów użytkowych i technicznych - o wysokim poziomie estetycznym, stała się świadectwem połączenia współczesnych potrzeb z szacunkiem do przeszłości. 


\section{Piśmiennictwo}

[1] Baranowski A., 1998. Projektowanie zrównoważone w architekturze, Gdańsk, 38.

[2] Dwór w Cianowicach. Gmina Skała. Zestawienie elementów zabytkowych. Aktualizacja, Projektant Marek. M. Łukacz, Marek J. Łukacz, Kraków 2010; Dokumentacja formalno-prawna i projektowa dla pałacu w Cianowicach udostępniona przez Właściciela obiektu (czerwiec 2015).

[3] Grzesiak R., 2004. Konserwacja i rewaloryzacja założeń pałacowo-ogrodowych w XXI w. na Dolnym Śląsku (wybrane przykłady), tom I, rozprawa doktorska na Wydziale Architektury Politechniki Wrocławskiej, promotor prof. dr hab. inż. arch. B. Stępniewska-Janowska, Wrocław, 6.

[4] Izquiredo-Encarnacion J.M.: Codes, Policies and Earthquakes as Aplied to Historic Preservation Projects, Conference on Structural Analysius of Historic Constructions, 2012, Wrocław, Poland, 94-104.

[5] Kadłuczka A., 2000. Ochrona Zabytków Architektury, Tom I, Kraków, 136-137.

[6] Karta Krakowska 2000, źródło: fhttp://www.zabytki-tonz.pl/pliki/Karta\%20Krakowska\%202000.pdf, (dostęp:17.07.2014).

[7] Majdecki L., 1993. Ochrona i konserwacja zabytkowych założeń ogrodowych, Warszawa, 24.

[8] Malesza J., Miedziałowski Cz., Malesza M., 2013. Techniczne aspekty odbudowy i utrzymania obiektów zespołu pokamedulskiego $w$ Wigrach/Technical aspects of reconstruction and preservation of the former Camaldolese monastery in Wigry, [w:] Wiadomości Konserwatorskie, K. Kuśnierz (red.), nr 36/2013, Warszawa, 18. Źródło: Izquiredo-Encarnacion J.M., 2012: Codes, Policies and Earthquakes as Aplied to Historic Preservation Projects, Conference on Structural Analysius of Historic Constructions, Wrocław, Poland, 94-104.

[9] Projekt budowlany zamienny przebudowy, rozbudowy i nadbudowy budynku dworskiego "Pałac W Cianowicach z wewnętrznymi instalacjami (wod-kan, gaz, co, wentylacji mechanicznej, instalacji chłodzenia, instalacji energii elektrycznej, niskoprądowa i odgromowa) i kotłownia gazowa wraz ze zmiana sposobu użytkowania budynku dworskiego na budynek mieszkalny jednorodzinny dwupokoleniowy oraz towarzysząca infrastruktura techniczna, dojścia dojazdy, miejsca postojowe wraz z odwodnieniem liniowym do zbiornika na wody opadowe na dziatce nr 402/14 w miejscowości Cianowice, gmina Skała; Dokumentacja formalno-prawna i projektowa dla pałacu w Cianowicach udostępniona przez Właściciela obiektu (czerwiec 2015).

[10] Pałac w Cianowicach. Gmina Skała. Program prac konserwatorskich elewacji, wątków ścian i sklepień części piwnic oraz stolarki drzwiowej, Projektant Barbara Łukacz, Marek J. Łukacz, Kraków 2011; Dokumentacja formalno-prawna i projektowa dla pałacu w Cianowicach udostępniona przez Właściciela obiektu (czerwiec 2015).

\section{Modernization of historical palace in Cianowice}

Summary: The historic foundation of architectural and garden in Cianowice near Krakow, a great good transmitted by previous generations, it was confirmation that regardless of the degree of preservation of the monument, through appropriate interference with the use of the modern and the introduction of a new substance, it was possible to restore the important significance of the object and place. This made it possible to rediscover the precious historical heritage. Restored again feature has become a tool to ensure that monument to function and effectively interact with the environment, the community - in the era of progressive world rapid development of civilizational Conferences, carrying behind threats leading to degradation of the cultural landscape, including the historic of park.

Keywords: modernization of the monument, palace, mansion, Cianowice 